\title{
Pengembangan repositori data pada lembaga riset dengan status Pusat Unggulan Ilmu Pengetahuan dan Teknologi
}

\author{
Cahyo Trianggoro1, Tupan², Mohamad Djaenudin ${ }^{3}$, Noorika Retno Widuri ${ }^{4}$, Rochani \\ Nani Rahayu ${ }^{5}$ \\ 1,2,3,4,5 Pusat Data dan Dokumentasi Ilmiah-Lembaga Ilmu Pengetahuan Indonesia \\ Jl. Jenderal Gatot Subroto 10, Kuningan Baru, Jakarta, 12710 \\ E-mail: ${ }^{1}$ cahy008@lipi.go.id, 2tupa001@lipi.go.id, ${ }^{3}$ moha008@lipi.go.id, ${ }^{4}$ noor004@lipi.go.id, \\ ${ }^{5}$ rochani002@lipi.go.id
}

Received: March 2020; Accepted: February 2021; Published: June 2021

\begin{abstract}
National regulations in science and technology mandate researchers, research institutions, and research funders to store and share research data. However, research institutions in Indonesia have not widely practiced research data management by utilizing institutional repositories. This study aimed to determine the development of repositories in research institutions under the Center of Excellence (PUI) supervision program from three aspects: policy, infrastructure, and organizational culture. This research used a quantitative approach through descriptive methods. Data was collected from the management of the research institute repository under the supervision program of the Center of Excellence (PUI), a program of the Ministry of Research and Technology/the National Research and Innovation Agency. The data were analyzed descriptively to see how the repository's development supported research activities. The study results indicated that most institutions had policies for managing institutional repositories on the policy side and needed to be reinforced by policies for managing research data. On the infrastructure aspect, most research institutions did not yet have a repository for research data management. While on aspects of cultural organization, most researchers realized that collaborative research activities could benefit from the institutional repository. This study concludes that research institutions can develop existing institutional repositories for research data management by reinforcing policies, improving the infrastructure function of institutional repositories, and building a culture of data management through campaigns and outreach.
\end{abstract}

Keywords: Institutional repository; Data repository; Research data

\begin{abstract}
Abstrak
Undang-undang sistem nasional ilmu pengetahuan dan teknologi Nomor 11 tahun 2019 mengamanatkan wajib serah simpan data penelitian kepada peneliti, lembaga penelitian, dan penyandang dana penelitian. Namun pengelolaan data penelitian yang memanfaatkan infrastruktur repositori institusi belum banyak dilakukan lembaga penelitian di Indonesia. Penelitian ini bertujuan melihat pengembangan repositori data pada lembaga riset dengan status Pusat Unggulan Ilmu Pengetahuan Teknologi (PUI) dari tiga aspek, kebijakan, infrastruktur, dan budaya organisasi. Penelitian ini menggunakan pendekatan kuantitatif dengan metode deskriptif. Data dikumpulkan dari pengelola repositori lembaga penelitian, yang masuk dalam pembinaan program Pusat Unggulan Ilmu Pengetahuan Teknologi Kementerian Riset dan Teknologi/Badan Riset dan Inovasi Nasional. Data dianalisis secara deskriptif untuk melihat bagaimana pengembangan repositori dalam mendukung kegiatan penelitian. Hasil penelitian menunjukkan bahwa dalam sisi kebijakan, sebagian besar lembaga memiliki kebijakan pengelolaan repositori lembaga dan perlu diperkuat dengan kebijakan pengelolaan data penelitian. Pada aspek infrastruktur, sebagian besar lembaga penelitian belum memiliki repositori untuk pengelolaan data penelitian. Pada aspek budaya organisasi, sebagian besar peneliti telah menyadari manfaat repositori lembaga yang dapat digunakan untuk kolaborasi kegiatan penelitian. Simpulan penelitian ini adalah lembaga penelitian dapat mengembangkan repositori institusi yang ada untuk pengelolaan data penelitian dengan memperkuat kebijakan, meningkatkan fungsi infrastruktur repositori institusi, serta membangun budaya organisasi pengelolaan data melalui kampanye dan sosialisasi.
\end{abstract}

Kata Kunci: Repositori institusi; Repositori data; Data penelitian 


\section{PENDAHULUAN}

Undang-Undang Republik Indonesia Nomor 11 Tahun 2019 Tentang Sistem Nasional Ilmu Pengetahuan dan Teknologi (2019) yang baru saja disahkan pemerintah mengamanatkan kepada peneliti, lembaga penelitian, pengkajian dan penerapan, lembaga penyandang dana untuk melakukan wajib serah simpan data dan karya hasil penelitian. Regulasi tersebut mengamanatkan bahwa lembaga penelitian, pengkajian, dan penerapan, penyandang dana, sumber daya manusia IPTEK untuk melakukan penyimpanan data dan keluaran hasil penelitian melalui sistem informasi IPTEK yang terintegrasi secara nasional sebagaimana tertuang dalam pasal 40 undang-undang tersebut. Namun selama ini, pengelolaan keluaran penelitian berupa data primer masih belum banyak mendapatkan perhatian peneliti maupun lembaga penelitian, pengkajian, dan penerapan.

Kegiatan pengelolaan data penelitian dengan memanfaatkan infrastruktur repositori institusi belum banyak dilakukan lembaga penelitian, pengkajian, dan penerapan, maupun perguruan tinggi di Indonesia sebagai pelaku kegiatan penelitian yang menghasilkan data dalam jumlah yang besar. Data penelitian masih tersimpan secara terpisah pada tempat penyimpanan pribadi peneliti, misalnya dalam laptop, komputer desktop, external hard disk, serta tempat penyimpanan lainnya. Hal ini terlihat dari sulitnya mendapatkan data penelitian yang telah dihasilkan peneliti dalam satu disiplin ilmu tertentu oleh peneliti lain yang ingin melakukan reproduksi kegiatan penelitian yang sejenis (Irawan \& Rachmi, 2018).

Repositori institusi di Indonesia memiliki fokus masih terbatas pada pengelolaan luaran penelitian berupa karya tulis ilmiah dan laporan hasil penelitian dari hasil akhir kegiatan penelitian. Repositori dalam pengelolaan data penelitian belum banyak diimplementasikan pada lembaga penelitian. Sejalan dengan amanat UndangUndang Republik Indonesia Nomor 11 Tahun 2019 Tentang Sistem Nasional Ilmu Pengetahuan dan Teknologi (2019) yang disinggung di awal, lembaga penelitian, pengkajian, dan penerapan perlu untuk melakukan pengembangan repositori yang dimiliki dalam rangka melaksanakan kewajiban manajemen data penelitian untuk preservasi jangka panjang dan diseminasi kegiatan penelitian.

Gerakan open science yang saat ini terjadi di berbagai belahan dunia melakukan pengelolaan data penelitian dengan memanfaatkan repositori data yang dikelola baik konsorsium keilmuan, seperti Inter-University Consortium for Political and Social Research (ICPSR) dan National Academic Research and Collaborations Information System (NARCIS) yang dikelola Data Archiving and Networked Services (DANS), lembaga pengelola data penelitian dibawah The Dutch Research Council (NWO) Belanda. Selain repositori data dalam tingkat nasional, Uni Eropa melalui European Open Science Cloud (EOSC) menyediakan infrastruktur riset berbasis cloud dalam memfasilitasi potensi penelitian agar data penelitian terkelola secara baik. Beberapa prinsip dan asas yang disepakati dalam pengelolaan data penelitian dikenal dengan istilah FAIR data principle, bahwa data penelitian harus mampu ditemukan kembali (findable), disediakan akses secara terbuka maupun terbatas (accessible), dapat dioperasikan pada beberapa platform (interoperable), dan dapat digunakan kembali (reusable). 
Gerakan open science di berbagai belahan dunia mendorong kegiatan penelitian untuk dilakukan secara lebih cermat, dapat dipertanggungjawabkan secara ilmiah melalui keterbukaan akses terhadap data penelitian yang digunakan peneliti sehingga dapat diuji coba peneliti lainnya yang memiliki ketertarikan terhadap suatu isu penelitian. Gerakan ini bermuara pada peningkatan kualitas penelitian secara alami. Di mana proses penelitian sampai hasil penelitian dapat terbuka kepada publik dan memungkinkan publik melakukan penilaian terhadap suatu topik penelitian. Sejalan dengan hal tersebut, Kementerian Riset Teknologi dan Pendidikan Tinggi (Kemenristekdikti) saat ini berubah nomenklatur ke Kementerian Riset dan Teknologi/Badan Riset dan Inovasi Nasional (Kemenristek/BRIN) yang memiliki suatu program pembinaan lembaga Ilmu Pengetahuan dan Teknologi yang dikenal dengan nama Pusat Unggulan Ilmu Pengetahuan dan Teknologi (PUI). Pusat Unggulan Ilmu Pengetahuan dan Teknologi bertujuan meningkatkan kapasitas dan kapabilitas kelembagaan, sumber daya, dan jaringan Ilmu Pengetahuan dan Teknologi dalam bidang yang lebih spesifik agar ada peningkatan relevansi, produktivitas, dan pendayagunaan IPTEK dalam sektor produksi untuk menumbuhkan perekonomian nasional. Hal ini pada gilirannya akan berdampak pada peningkatan kesejahteraan masyarakat.

Keberadaan repositori institusi merupakan aset penting bagi lembaga riset sebagai penguat kedudukan pusat unggulan (center of excellent). Posisi tersebut menjadikan institusi riset sebagai pusat pengelolaan pengetahuan sekaligus mendukung diseminasi informasi riset dalam bentuk karya hasil penelitian, model produk, maupun data penelitian agar penelitian berdampak secara lebih luas di masyarakat dan pengembangan ilmu pengetahuan. Ketersediaan data penelitian yang dapat digunakan kembali (reproducible) memberikan beragam manfaat dalam suatu ekosistem riset. Hal ini mampu mendorong berbagai bentuk kolaborasi antar-pemangku kepentingan dalam ekosistem riset dan akselerasi kemajuan ilmu pengetahuan dan teknologi yang pada gilirannya akan memantik inovasi peneliti. Maka penelitian akan lebih efisien dengan memanfaatkan data yang telah tersedia di repositori institusi (Mueller-Langer \& Andreoli-Versbach, 2018).

Repositori institusi merupakan salah satu infrastruktur penelitian yang memungkinkan peneliti melakukan pengelolaan output hasil penelitian berupa karya tulis ilmiah, data penelitian, dan bentuk lainnya. Repositori juga bermanfaat sebagai salah satu sarana dalam melakukan manajemen pengetahuan (knowledge management). Beberapa manfaat keberadaan repositori institusi, antara lain dapat meningkatkan prestise sebagai bentuk promosi lembaga sehingga menarik pendanaan riset dan potensi kolaborasi lainnya (Ulum \& Setiawan, 2016). Selain itu, repositori dalam kegiatan promosi memberikan manfaat sebagai sarana dalam melakukan preservasi hasil penelitian sekaligus media untuk disebarluaskan kepada masyarakat (Yaniasih, Ardiansyah, \& Sulistyo-Basuki, 2015).

Repositori institusi terkait data penelitian sebagai salah satu infrastruktur dalam ekosistem riset yang mendorong terjadinya kolaborasi riset serta pemanfaatan hasil riset oleh seluruh 
pemangku kepentingan (RDA Covid-19 Working Groups, 2020). Ketersediaan data penelitian yang disertai akses terbuka dalam repositori institusi tentunya akan mereduksi kegiatan penelitian yang berulang pada satu masalah yang sama. Hal ini mempercepat penciptaan pengetahuan baru dan pemecahan suatu masalah melalui kegiatan penelitian agar berjalan secara lebih efisien. Penelitian terdahulu terkait repositori insititusi masih terbatas pada repositori yang dimanfaatkan untuk mengelola keluaran hasil penelitian, seperti laporan penelitian, tesis, dan disertasi (Asmad et al., 2018). Penelitian ini berupaya untuk mengisi kekosongan pada area pengembangan repositori yang dapat dimanfaatkan untuk pengelolaan data penelitian.

Namun demikian, pemanfaatan data penelitian melalui repositori institusi tentunya memiliki beberapa tata tertib yang harus dipatuhi seperti etika, aspek hukum, jaminan hak kekayaan intelektual, dan jaminan kerahasiaan terhadap data sensitif. Proses pendokumentasian data dilakukan mulai saat data diciptakan sampai data dipublikasikan sebagai syarat mutlak agar memiliki konteks yang utuh. Hal ini bermanfaat bagi pengguna data agar dapat memberikan interpretasi data yang tepat ketika akan menggunakan kembali data yang tersedia pada repositori institusi. Selain itu, repositori institusi pun memerlukan suatu standar terkait sistem infrastruktur repositori data yang disepakati seluruh pemangku kepentingan sehingga pemanfaatan data penelitian oleh komunitas ilmiah dapat berjalan secara lebih mulus.

Maka untuk mewujudkan hal tersebut, diperlukan suatu kajian awal untuk melihat bagaimana kondisi repositori institusi lembaga penelitian, pengkajian, dan penerapan yang masuk dalam pembinaan maupun dalam penetapan Pusat Unggulan Ilmu Pengetahuan dan Teknologi. Lembaga penelitian, pengkajian, dan penerapan dapat menyusun strategi yang diperlukan untuk pengembangan repositori institusi. Pemerintah pusat dapat melahirkan kebijakan yang tepat dalam menyikapi kondisi repositori institusi di Indonesia sehingga implementasi dari UndangUndang Republik Indonesia Nomor 11 Tahun 2019 Tentang Sistem Nasional Ilmu Pengetahuan dan Teknologi (2019) dapat berjalan dengan baik. Pemerintah pusat pun dapat menyusun strategi dalam membangun model sistem informasi IPTEK yang terintegrasi dalam rangka membangun repositori ilmiah dalam skala nasional. Hal ini diperlukan untuk membantu mendekatkan sains kepada masyarakat luas.

Sehubungan dengan hal tersebut, penelitian ini bertujuan menggali strategi pengembangan repositori yang dilakukan institusi lembaga Pusat Unggulan Ilmu Pengetahuan dan Teknologi sehingga dapat bermanfaat sebagai sarana pengelolaan pengetahuan yang dilihat dari tiga aspek di antaranya aspek kebijakan, aspek ketersediaan infrastruktur, dan aspek budaya organisasi.

\section{METODE PENELITIAN}

Penelitian ini menggunakan pendekatan kuantitatif melalui metode penelitian deskriptif, yakni metode penelitian yang bertujuan untuk menggambarkan fenomena beserta dengan karakteristiknya. Metode penelitian ini lebih cenderung untuk menjawab pertanyaan tentang fenomena apa yang ada dibandingkan menjawab pertanyaan bagaimana dan mengapa 
suatu fenomena muncul (Nassaji, 2015). Analisis deskriptif kuantitatif dilakukan terhadap data yang telah dikumpulkan dilakukan untuk memperoleh gambaran kondisi kebijakan repositori, ketersediaan infrastruktur, serta kondisi budaya organisasi terkait dengan pengelolaan data penelitian.

Kegiatan penelitian dilakukan sejak Maret 2019 hingga November 2019. Hamdi and Bahruddin (2014) mengatakan bahwa dalam teknik pengumpulan data dapat menggunakan kuesioner, wawancara terencana, tes, observasi terencana, inventarisasi, skala rating, dan ukuran biasa. Peneliti dalam penelitian ini menggunakan teknik pengumpulan data berupa kuesioner kepada 19 responden dan wawancara terencana kepada 8 responden. Adapun responden dalam penelitian ini menggunakan jenis purposive sampling, yakni responden dipilih sesuai kriteria penelitian. Responden dipilih sesuai kriteria yang telah ditentukan yakni pengelola repositori di setiap organisasi dan responden yang memiliki pemahaman mendalam terkait pengelolaan repositori.

Pertama, teknik pengumpulan data melalui kuesioner dilakukan secara daring kepada pengelola repositori lembaga penelitian, pengkajian, dan penerapan yang telah masuk dalam status Penetapan Pusat Unggulan Ilmu Pengetahuan dan Teknologi-Kementrian Riset Teknologi dan Pendidikan Tinggi (KemenristekDikti). Kedua, teknik pengumpulan data melalui wawancara dilakukan terhadap pengelola repositori untuk mendapatkan data yang lebih mendalam terkait kondisi yang melatarbelakangi pengelolaan repositori institusi serta terkait dengan budaya organisasi. Pengelola repositori yang diwawancarai merupakan orangorang yang mempunyai kapasitas dan kemampuan dalam mengelola repositori di lembaga penelitian, pengkajian, dan penerapan dengan status Pusat Unggulan Ilmu Pengetahuan dan Teknologi dari Kemenristekdikti. Data hasil kuesioner dan wawancara yang telah berhasil dikumpulkan dianalisis menggunakan teknik analisis deskriptif. Analisis deskriptif dilakukan untuk memperoleh gambaran kondisi repositori institusi pada lembaga penelitian.

Kegiatan penelitian profil repositori data ini masih terbatas pada pengumpulan data penelitian dari sisi pengelola repositori institusi. Dengan demikian, untuk mendapatkan gambaran yang lebih utuh, diperlukan pengumpulan data dari sisi peneliti pada lembaga penelitian, pengkajian, dan penerapan dengan status Pusat Unggulan Ilmu Pengetahuan dan Teknologi untuk melihat dampak dari ketersediaan repositori data.

\section{HASIL DAN PEMBAHASAN}

Repositori institusi merupakan salah satu infrastruktur dalam ekosistem riset yang mendukung kegiatan penelitian. Repositori institusi menyediakan berbagai sumber referensi yang dapat dimanfaatkan oleh siapa saja yang membutuhkan pengetahuan berupa hasil penelitian, pengkajian, dan penerapannya. Ketersediaan repositori yang representatif, mutakhir, dan mudah diakses merupakan suatu keharusan agar repositori dapat termanfaatkan dengan baik oleh sumber daya IPTEK dalam lingkup internal dan eksternal lembaga.

Ketersediaan sumber informasi berupa literatur, data, dan sumber informasi lainnya dalam suatu repositori akan mendorong terciptanya akumulasi pengetahuan secara lebih masif (Vasilevsky, Minnier, Haendel, \& 
Champieux, 2017). Selain sebagai sumber referensi, repositori institusi pun menyimpan keluaran hasil penelitian dalam jangka panjang, berupa laporan hasil penelitian, karya tulis ilmiah, data penelitian, dan bentuk lainnya. Pengelolaan data penelitian melalui repositori juga memungkinkan suatu komunitas ilmiah melakukan pengujian (peer review) terhadap output penelitian dengan menguji kembali data penelitian yang tersedia sehingga kualitas suatu riset dapat lebih dipertanggungjawabkan (Groom, Desmet, Vanderhoeven, \& Adriaens, 2015).

Selain itu, pengelolaan dan pengembangan repositori institusi perlu dilihat secara holistik dari berbagai aspek yang melingkupinya dalam satu kesatuan ekosistem. Repositori tidak hanya bertumpu pada aspek pengembangan teknologi informasi semata, namun juga ditinjau dari sisi non teknologi. Keberlangsungan dan pengembangan repositori perlu didukung suatu ekosistem yang saling berkaitan satu dengan lainnya. Pengembangan repositori insititusi tidak dapat terlepas dari adanya kebijakan lembaga dalam mengelola keluaran hasil penelitian berupa karya tulis ilmiah maupun data penelitian. Kebijakan institusi lebih memegang peranan penting dalam menjamin keberlangsungan pengelolaan keluaran hasil penelitian melalui repositori institusi (Higman \& Pinfield, 2015).

Intervensi dari kebijakan penyandang dana penelitian pun turut berperan serta terhadap keberlangsungan tata kelola data penelitian dengan memanfaatkan repositori data penelitian. Pengelola dana penelitian yang mendapatkan dana dari publik sudah semestinya mewajibkan kepada penerima hibah untuk membuka data penelitian secara terbuka. Penyandang dana penelitian yang terlibat aktif sangat penting mengingat kegiatan penelitian bergantung terhadap ketersediaan dana penelitian (Bates, 2017). Kebijakan terkait repositori pun sebagai pijakan bagi lembaga dalam penerapan, pengelolaan, serta pengembangan repositori institusi (Ulum \& Setiawan, 2016).

Berdasarkan kuesioner yang telah dikumpulkan, dapat diketahui bahwa lebih dari 50\% lembaga telah memiliki kebijakan terkait repositori institusi. Jumlah ini mencerminkan bahwa lembaga penelitian memiliki kesadaran akan pentingnya kebijakan lembaga dalam pengelolaan repositori. Responden sebanyak 30\% mengonfirmasikan belum memiliki kebijakan terkait pengelolaan repositori untuk level institusi sebagaimana tergambar dari tabel 1.

Tabel 1

Kondisi kebijakan repositori

\begin{tabular}{llll}
\hline No & Kategori jawaban & $\mathbf{f}$ & $\mathbf{\%}$ \\
\hline 1 & Sudah memiliki & 13 & 68,6 \\
2 & Belum memiliki & 6 & 31,4 \\
& Jumlah & 19 & 100 \\
\hline
\end{tabular}

Sumber: Berdasarkan hasil penelitian, 2019

Berdasarkan tabel 1, sebagian besar lembaga telah memiliki kebijakan terkait repositori. Kebijakan pengelolaan repositori institusi merupakan faktor penting yang dapat mencerminkan komitmen organisasi dalam pengelolaan keluaran hasil penelitian (Higman \& Pinfield, 2015).

Data ini diperkuat dari hasil wawancara yang dilakukan terhadap responden. Para responden telah memiliki kebijakan terkait repositori institusi. Namun implementasi di lapangan tidak 
dapat berjalan mulus. Kebijakan tersebut belum mampu menjalankan mekanisme yang mengikat peneliti untuk melakukan pengelolaan keluaran hasil penelitian. Maka, diperlukan suatu peninjauan kembali terhadap kebijakan yang ada melalui perumusan mekanisme yang tepat terkait kewajiban peneliti untuk mengelola keluaran hasil penelitian melalui sistem repositori institusi.

Selain kebijakan institusi, pengelolaan data penelitian pada level operasional diperlukan suatu panduan yang lebih bersifat teknis yang membagi peran antara peneliti dan pengelola data penelitian. Pada umumnya, hal ini diperankan perpustakaan pada lembaga penelitian maupun perguruan tinggi. Panduan operasional dan kebijakan pengelolaan data pada level institusi perlu mendapatkan perhatian lembaga penelitian dan perguruan tinggi yang dibuat secara terpisah untuk memudahkan peneliti mengimplementasikan pengelolaan kebijakan data pada tataran tujuan dan mekanisme (Neylon, 2017).

Hal ini didukung pernyataan Irawan, Darujati, Soebandhi, Hayati, and Sari (2018) bahwa saat ini belum ada panduan terkait pengelolaan output hasil penelitian dari otoritas pusat sampai level institusi. Oleh karena itu, pemerintah pusat diharapkan dapat melakukan akselerasi perumusan peraturan pemerintah dan turunannya sebagai implementasi dari Undang-Undang Republik Indonesia Nomor 11 Tahun 2019 Tentang Sistem Nasional Ilmu Pengetahuan dan Teknologi (2019) Pasal 40 pada angka (1) sampai (9). Kondisi lembaga penelitian, pengkajian, dan penerapan dalam konteks kesadaran penting mengelola keluaran hasil penelitian melalui repositori lembaga. Maka, hal ini perlu didorong lebih kuat lagi melalui mekanisme yang terperinci dalam mengelola data penelitian melalui repositori institusi, seperti penyusunan panduan manajemen data.

Adapun penyandang dana berperan sebagai lembaga penelitian, pengkajian, dan penerapan yang melakukan tugas dan fungsi operasional kegiatan penelitian dan berkewajiban mendorong kegiatan pengelolaan data penelitian. Intervensi kebijakan berguna bagi penyandang dana penelitian agar dapat mendorong pelaku riset untuk mengelola data dengan memanfaatkan repositori institusi. Beberapa organisasi penyandang dana internasional menetapkan kebijakan terkait dengan pengelolaan data penelitian di Belanda seperti Netherlands Organisation for Scientific Research (NWO) yang menetapkan kebijakan data contract, yakni suatu kewajiban bagi peneliti yang mendapatkan hibah penelitian dari NWO untuk menyimpan data penelitian pada repositori yang disediakan oleh Data Archiving and Networked Services (DANS). Kebijakan ini memuat prosedur pengelolaan data yang bertujuan untuk menjamin data penelitian untuk dapat ditelusur di kemudian hari dan dapat digunakan untuk penelitian dan analisis lebih lanjut di masa yang akan datang oleh pemilik data dan peneliti lain. Lebih jauh lagi, melalui kebijakan data contract, verifikasi kebenaran ilmiah dapat lebih terjamin karena keterbukaan data akan mendorong komunitas ilmiah untuk melakukan pengujian terhadap validitas data yang digunakan (Zuiderwijk, Shinde, \& Jeng, 2020).

Penyandang dana, selain Belanda, yang telah menerapkan intervensi kebijakan yang serupa adalah Research Council United Kingdom (RCUK). Lembaga ini berubah nama United Kingdom Research and Innovation (UKRI), merupakan lembaga independen yang memiliki tugas 
mengelola pendanaan penelitian serta mengnyinergikan kegiatan penelitian sesuai kebutuhan masyarakat dan industri. Belanda melakukan pendekatan top down approach, sedangkan Research Council United Kingdom cenderung memiliki pendekatan yang lebih bersifat bottom up approach. Research Council United Kingdom mencoba menginisiasikan penyusunan suatu panduan terkait pengelolaan data penelitian yang berkolaborasi dengan komunitas ilmiah di Inggris.

Panduan ini disepakati dan digunakan secara luas lembaga penelitian, pengkajian, dan penerapan di Inggris. Dokumen panduan yang bernama Concordat on Open Research Data berisi tentang prinsip dan mekanisme pengelolaan data penelitian secara komprehensif dan akuntabel. Dokumen ini memiliki tujuan memastikan data penelitian yang didanai dari anggaran negara (publically funded research) dapat ditelusuri dengan mudah saat dibutuhkan dan dapat dibuka kepada publik ketika memang memungkinkan. Selain itu, melalui keterbukaan data penelitian diharapkan kualitas hasil penelitian semakin baik yang muaranya akan mendorong inovasi serta meningkatkan kepercayaan publik terhadap kegiatan penelitian (UK multi-stakeholder group, 2020).

Indonesia saat ini sudah memiliki kebijakan pada tingkat nasional terkait kewajiban serah simpan data yang diamanatkan melalui Undang-Undang Republik Indonesia Nomor 11 Tahun 2019 Tentang Sistem Nasional Ilmu Pengetahuan dan Teknologi (2019) pada Pasal 40 yang menerangkan bahwa, "Penyandang dana penelitian, sumber daya manusia ilmu pengetahuan dan teknologi, serta kelembagaan ilmu pengetahuan dan teknologi, untuk melakukan wajib serah dan wajib simpan data penelitian." Hal ini sebagai amanat nasional yang dituangkan dalam peraturan perundang-undangan dan harapan baru bagi dunia Ilmu Pengetahuan dan Teknologi. Maka, pemerintah pusat yang membidangi urusan pengembangan ilmu pengetahuan dan teknologi wajib memperhatikan pengelolaan data penelitian.

Berdasarkan regulasi ini, diperlukan suatu peraturan pelaksana yang mengatur secara teknis mekanisme, kelembagaan, hak dan kewajiban yang lebih terperinci sebagai panduan bagi lembaga penelitian, pengembangan, pengkajian, dan penerapan untuk melakukan pengelolaan keluaran hasil penelitian secara lebih sistematis. Penyusunan peraturan pelaksana dari Undang-Undang Republik Indonesia Nomor 11 Tahun 2019 Tentang Sistem Nasional Ilmu Pengetahuan dan Teknologi (2019) Pasal 40, dapat mengadaptasikan dari pola yang dibangun Inggris melalui UK Research and Innovation dengan melibatkan seluruh pemangku kepentingan dalam dunia penelitian, pengkajian, dan penerapan di Indonesia. Adapun bottom up approach, dapat dipertimbangkan dalam pendekatan yang bisa dipilih dalam menyusun suatu kebijakan terkait pengelolaan data penelitian. Kebijakan yang lahir dari pendekatan ini akan menghasilkan kebijakan yang bersifat partisipatif sehingga pada tataran pelaksanaan diharapkan dapat berjalan dengan lebih baik.

Pada tabel 2, sebagian besar peneliti menyatakan bahwa lembaga belum mewajibkan peneliti untuk menyimpan data dan karya dalam repositori lembaga. Hal ini mengindikasikan bahwa banyak lembaga penelitian, pengkajian, dan penerapan belum menaruh perhatian besar terhadap pengelolaan keluaran hasil penelitian dalam bentuk kebijakan lembaga. 
Tabel 2

Kewajiban menyimpan data dan karya dalam repositori

\begin{tabular}{llll} 
No & Kategori jawaban & f & \% \\
\hline 1 & Sangat setuju & 2 & 10,5 \\
2 & Setuju & 7 & 36,8 \\
3 & Kurang setuju & 8 & 42,1 \\
4 & Tidak setuju & 2 & 10,5 \\
5 & Sangat tidak setuju & 0 & 0 \\
& Jumlah & 19 & 100 \\
\hline
\end{tabular}

Sumber: Berdasarkan hasil penelitian, 2019

Situasi tersebut dapat dipahami mengingat kewajiban terkait wajib serah simpan data penelitian baru saja disahkan pada saat kegiatan penelitian ini dilakukan. Untuk itu, kebijakan dapat disusun ke arah operasional atau teknis pada level institusional atau lembaga. Kebijakan teknis diperlukan sebagai panduan bagi para pengelola data penelitian baik dari sisi produsen data dan pengelola data (Higman \& Pinfield, 2015). Pembagian peran antarpemangku kepentingan pun perlu dituangkan secara lebih spesifik.

Adapun sebagian responden lainnya, menyatakan bahwa 36,8\% lembaga telah mewajibkan peneliti untuk menyimpan keluaran hasil penelitian melalui repositori lembaga. Data penelitian merupakan aset yang sangat berharga dalam kegiatan penelitian dan pengembangan. Berikut pernyataan responden.

"Sebenarnya dari pihak atau bidang pengelolaan dan informasi sudah memfasilitasi para peneliti untuk bersama-sama membangun sistem repositori, tetapi banyak faktor seperti kultur belum terbangun, tidak ada aturan, tidak mempunyai tenaga teknis, dan sebagainya sehingga tidak bisa berjalan dengan semestinya" (G. Wati, wawancara, August 23, 2019).
Saat ini data penelitian merupakan "mata uang baru" dalam kegiatan penelitian dan pengembangan. Oleh karena itu, diperlukan suatu pengelolaan yang baik agar potensi yang dimiliki data penelitian dapat termanfaatkan secara optimal. Kondisi infrastruktur repositori pada lembaga riset di Indonesia sangat beragam. Saat ini repositori yang dimiliki lembaga penelitian, pengkajian, dan penerapan masih berdiri sendiri di setiap lembaga. Pemerintah pusat memiliki kesulitan mengetahui hasil penelitian yang dihasilkan lembaga penelitian melalui satu sistem informasi Ilmu Pengetahuan dan Teknologi yang terintegrasi. Mayoritas lembaga penelitian, pengkajian, dan penerapan telah memiliki repositori yang digunakan untuk mengelola karya hasil penelitian sebagaimana tergambar pada tabel 3. Berdasarkan data dari responden yang berjumlah 19 lembaga, seluruh lembaga telah memiliki repositori yang digunakan untuk mengelola karya hasil penelitian.

Tabel 3

Repositori penyimpanan karya

\begin{tabular}{llll}
\hline No & Kategori jawaban & $\mathbf{f}$ & $\mathbf{0}$ \\
\hline 1 & Sudah memiliki & 19 & 100 \\
2 & Belum memiliki & 0 & 0 \\
& Jumlah & 19 & 100 \\
\hline
\end{tabular}

Sumber: Berdasarkan hasil penelitian, 2019

Maka dapat dipahami bahwa output hasil penelitian sejauh ini perlu didokumentasikan sebagai bentuk pertanggungjawaban atas penggunaan dana publik yang harus disampaikan kepada masyarakat pada saat monitoring dan evaluasi program kegiatan. Adapun repositori yang digunakan pengelolaan data penelitian masih belum mendapatkan 
perhatian dari para Sumber Daya Manusia (SDM) Ilmu Pengetahuan dan Teknologi di lembaga penelitian, pengkajian, dan penerapan. Kondisi seperti ini pada dasarnya dapat membawa keuntungan sekaligus kerugian di Indonesia.

$\begin{array}{ccc}\text { Lembaga } & \text { penelitian } & \text { harus } \\ \text { menyiapkan } & \text { infrastruktur } & \text { dalam }\end{array}$ membuka kesempatan bagi pemerintah pusat menetapkan sistem repositori yang dikehendaki untuk dapat digunakan sebagai sistem nasional. Hal ini akan lebih memudahkan dari sisi interoperabilitas dalam pertukaran data antar-lembaga karena memiliki standar yang sama. Para pengelola repositori institusi perlu memperhatikan arsitektur terbuka dan sumber kode yang terbuka (open source) untuk membuat basis pengembangan repositori institusi agar mekanisme interoperabilitas dalam pertukaran data dapat dilakukan secara lebih mudah (Rahman \& Watabe, 2018).

Di sisi lain, belum tersedianya repositori data bagi lembaga penelitian dalam memunculkan potensi data yang hilang karena data tidak tersimpan pada fasilitas penyimpanan institusi yang reliabel. Selain itu, alternatif lain dalam pengembangan repositori yang dapat dipertimbangkan adalah pemanfaatan infrastruktur pengelolaan data penelitian nasional. Pusat Data dan Dokumentasi Ilmiah-Lembaga Ilmu Pengetahuan Indonesia (PDDI-LIPI) menginisiasikan hal ini dengan nama Repositori Ilmiah Nasional (RIN). Repositori ini berbasis Dataverse yang didedikasikan untuk penyimpanan data penelitian serta dapat dimanfaatkan untuk berbagi data dalam kegiatan kolaborasi penelitian baik dalam internal dan eksternal lembaga (Riyanto, Marlina, Subagyo, Triasih, \& Yaman, 2021).
Tabel 4

Respon terkait pengembangan repositori untuk penyimpanan data

\begin{tabular}{llll}
\hline No & Kategori jawaban & $\mathbf{f}$ & \% \\
\hline 1 & Sangat setuju & 5 & 26,3 \\
2 & Setuju & 12 & 63,2 \\
3 & Kurang setuju & 2 & 10,5 \\
4 & Tidak setuju & 0 & 0 \\
5 & Sangat tidak setuju & 0 & 0 \\
& Jumlah & 19 & 100 \\
\hline
\end{tabular}

Sumber: Berdasarkan hasil penelitian, 2019

Berdasarkan mayoritas responden, pengembangan repositori yang dikelola lembaga penelitian, pengkajian, dan penerapan bertujuan untuk mengembangkan repositori institusi agar dapat digunakan untuk pengelolaan data penelitian. Repositori data penelitian diperlukan untuk memudahkan peneliti melakukan reproduksi penelitian menggunakan data set yang sama sehingga kegiatan riset dapat dilakukan secara lebih efisien dari segi pendanaan, waktu, dan tenaga (Charte, Charte, Rivera, del Jesus, \& Herrera, 2016).

Lembaga penelitian dapat mengimplementasikan repositori data, mengkaji, dan menerapkan baik pemerintah maupun swasta melalui pemanfaatan repositori yang bersifat open source. Hal ini bertujuan untuk pengembangan yang berkelanjutan oleh komunitas. Di mana lembaga penelitian, pengkajian, dan penerapan tidak bergantung sepenuhnya pada pengembang dari sisi internal (software developer). Selain itu, aplikasi repositori memiliki keuntungan dari segi pengembangan software yang lebih terjamin dan data open source yang menguntungkan lembaga sehingga efisien dari sisi anggaran. Beberapa repositori 
data open source yang dapat dimanfaatkan, antara lain Dataverse, Figshare, CKAN, Dryad, Zenodo. Beberapa sistem tersebut tentunya memiliki beragam keunggulan dan kelemahan yang dapat disesuaikan dengan kebutuhan lembaga.

\section{Tabel 5}

Kriteria jawaban responden terkait keberadaan repositori yang dilengkapi fasilitas penyimpanan dan pencarian data

\begin{tabular}{llll}
\hline No & Kategori jawaban & f & \% \\
\hline 1 & Sangat setuju & 2 & 10,5 \\
2 & Setuju & 7 & 36,8 \\
3 & Kurang setuju & 8 & 42,1 \\
4 & Tidak setuju & 2 & 10,5 \\
5 & Sangat tidak setuju & 0 & 0 \\
& Jumlah & 19 & 100 \\
\hline
\end{tabular}

Sumber: Berdasarkan hasil penelitian, 2019

Sesuai Undang-Undang Republik Indonesia Nomor ll Tahun 2019 Tentang Sistem Nasional Ilmu Pengetahuan dan Teknologi (2019) mengamanatkan bahwa pengelolaan seluruh data primer dan keluaran hasil penelitian harus dilakukan melalui sistem informasi ilmu pengetahuan dan teknologi yang terintegrasi secara nasional. Dengan demikian, ada beberapa alternatif yang dapat dilakukan pemerintah pusat dalam membangun model repositori yang terintegrasi secara nasional, di antaranya bersifat sentralisasi (centralized model) dan bersifat desentralisasi (federated model) (Meeker et al., 2015). Setiap model arsitektur sistem tersebut memiliki kelebihan dan kekurangan. Namun, melihat kondisi infrastruktur saat ini, model yang terdistribusi dapat dipertimbangkan pemerintah pusat dalam mengembangkan infrastruktur tersebut.

Meskipun model arsitektur sistem terdistribusi, masing-masing repositori tetap harus mampu terintegrasi satu sama lain sehingga Indonesia dapat memiliki suatu repositori berskala nasional yang dapat memberikan gambaran utuh mengenai kegiatan penelitian dan hasil penelitian yang dihasilkan Sumber Daya Manusia Ilmu Pengetahuan dan Teknologi Indonesia. Untuk itu, diperlukan suatu studi khusus yang lebih komprehensif untuk mempertimbangkan model infrastruktur yang dapat diterapkan dalam skala nasional di konteks Indonesia. Studi ini perlu dilakukan secara holistik, tidak hanya mengkaji sisi teknis saja. Namun, sisi sosiokultural pun dikaji sehingga implementasi dapat diterima banyak pihak dan berjalan secara mulus. Kegiatan penelitian yang tumpang tindih dan berulang dapat dikurangi sehingga pertumbuhan akumulasi pengetahuan dapat berlangsung lebih cepat lagi.

Adapun budaya pengelolaan output hasil penelitian merupakan salah satu faktor penting dalam mendorong kegiatan pengelolaan keluaran hasil penelitian agar berjalan secara optimal. Budaya ini lahir melalui serangkaian proses internalisasi dan akhirnya sebagai salah satu budaya organisasi. Salah satu bentuk budaya pengelolaan keluaran hasil penelitian dapat dilihat dari kesadaran para peneliti tentang repositori institusi yang dapat digunakan untuk menyimpan dan melakukan preservasi output hasil penelitian. Repositori institusi sebagai akumulasi pengetahuan agar dapat dimanfaatkan pihak internal dan eksternal dalam jangka panjang.

Tingkat kesadaran (awareness) peneliti terhadap fasilitas repositori untuk penyimpanan data dan karya hasil penelitian cukup tinggi. Mayoritas responden menjawab setuju bahwa repositori dapat digunakan untuk menyimpan data dan karya keluaran hasil penelitian sebesar 47,4\%. Kemudian, responden sebesar 10,5\% menjawab sangat setuju terkait keberadaan 
repositori untuk digunakan menyimpan data dan karya keluaran penelitian. Sesuai hal ini, dapat diartikan bahwa mayoritas responden telah mengetahui bahwa repositori dapat dimanfaatkan untuk penyimpanan karya penelitian dan dimanfaatkan lebih jauh sebagai penyimpanan data penelitian sebagaimana dimuat dalam tabel 6 .

Adapun sebagian responden lain yang menyatakan kurang setuju sebesar 26,3\% dan tidak setuju sebesar 15,8\% terkait pemanfaatan data dan karya. Peneliti kemudian menindaklanjuti dengan memberikan penjelasan sebagai pilihan jawaban melalui wawancara.

\section{Tabel 6}

Kriteria jawaban responden terkait pengetahuan peneliti mengenai ketersediaan repositori untuk menyimpan data dan karya

\begin{tabular}{llll}
\hline No & Kategori jawaban & f & \% \\
\hline 1 & Sangat setuju & 2 & 10,5 \\
2 & Setuju & 9 & 47,4 \\
3 & Kurang setuju & 5 & 26,3 \\
4 & Tidak setuju & 3 & 15,8 \\
5 & sangat tidak setuju & 0 & 0 \\
& Jumlah & 19 & 100
\end{tabular}

Sumber: Berdasarkan hasil penelitian, 2019

Responden menyatakan bahwa muncul kecenderungan ketidaksetujuan lembaga terkait repositori. Padahal repositori digunakan untuk keperluan penyimpanan data penelitian mengingat data penelitian merupakan aset yang sensitif dan bersifat rahasia di kalangan peneliti. Responden menjelaskan.

"Dalam menyimpan data penelitian para peneliti sudah melakukan pencatatan di log book online sehingga ketika diminta data mentah ke dalam repositori RIN agak keberatan, tetapi kalau diminta laporan hasil bisa dan itu sudah ada datanya (data mentah) di Tata Operasional" (R. Sumadi, wawancara, August 30, 2019).

Responden khawatir data penelitian yang disimpan di repositori memiliki resiko diretas pihak yang tidak bertanggung jawab dan digunakan untuk kepentingan lain. Hal ini cukup beralasan mengingat saat ini data penelitian merupakan aset yang sangat berharga dari sebuah penelitian (Vasilevsky et al., 2017). Oleh karena itu, sosialisasi pentingnya manajemen data penelitian sangat diperlukan untuk meyakinkan peneliti bahwa penyimpanan data melalui sistem repositori institusi pada dasarnya justru untuk mencegah hal yang tidak diinginkan terkait kehilangan data atau pencurian data.

Selain itu, infrastruktur repositori institusi juga perlu dikembangkan untuk mengelola keluaran hasil penelitian berupa karya tulis ilmiah dan data penelitian.

"Khusus kegiatan PUI Bioprospeksi telah dibuat sistem penyimpanan data sebagai output kegiatan yang diberi nama Indonesia Marine Natural Product Database dapat diakses secara online. Menu database tersebut adalah penelitian, stasiun, daftar spesies, daftar kimia, dan publikasi" (M. Y. Putra, wawancara, September 5, 2019).

Beberapa sistem penyimpanan data sudah didukung menggunakan beberapa fitur keamanan, seperti pengaturan akses terhadap data penelitian dan kerahasiaan data penelitian. Maka, para peneliti tidak perlu lagi khawatir untuk menyimpan keluaran hasil penelitian pada repositori institusi. Selain itu, repositori institusi bertujuan sebagai penyimpanan keluaran hasil penelitian dan sarana kolaborasi kegiatan penelitian baik dalam satu disiplin atau antardisiplin keilmuan 
(Meeker et al., 2015). Komunitas ilmiah pun melalui repositori institusi dapat mengetahui topik riset yang telah atau sedang dikerjakan peneliti lain dan mengetahui kepakaran seseorang dari luaran penelitian yang dihasilkan. Untuk itu, kolaborasi penelitian sangat penting bagi peneliti, terutama peneliti di Indonesia. Hal ini mengingat Indonesia sebagai negara berkembang yang belum memiliki anggaran penelitian sebesar negara maju. Kegiatan penelitian yang efisien melalui kolaborasi dapat dilakukan melalui publikasi data penelitian sebelum suatu artikel ilmiah diterbitkan pada suatu jurnal sehingga produktivitas peneliti dapat dioptimalkan. Repositori sendiri memiliki fitur access management yang memungkinkan peneliti berkolaborasi dengan peneliti lain dalam satu lembaga maupun antarlembaga tanpa terhalang ruang dan waktu. Sistem repositori mendukung kegiatan kolaborasi agar kegiatan penelitian dapat berjalan secara lebih efisien dengan berbagai sumber daya riset bagi seluruh peneliti di Indonesia.

Saat ini, beberapa kolaborasi penelitian yang memanfaatkan repositori data sebagai sarana untuk mengakses data set telah tren dalam kegiatan penelitian. Model kolaborasi penelitian banyak yang termotivasi dari budaya berbagi data (data sharing) yang dapat dilakukan penelusuran melalui repositori data yang dimiliki suatu komunitas keilmuan, seperti pada bidang kesehatan (medical science) atau bahkan repositori data yang dimiliki oleh konsorsium keilmuan (Cheah, Day, Parker, M., \& Bull, 2017; Fusi, Manzella, Louafi, \& Welch, 2018; Groom et al., 2015; Rahman \& Watabe, 2018).

Pada penelitian ini, responden setuju dengan konsep kolaborasi kegiatan penelitian agar dapat difasilitasi menggunakan repositori institusi. Responden sebanyak 36,8\% menyatakan sangat setuju bahwa repositori dapat memfasilitasi kolaborasi antardisiplin ilmu. Adapun jumlah lembaga yang menyatakan setuju bahwa repositori institusi dapat memfasilitasi kolaborasi antardisiplin sebesar 63,2\%.

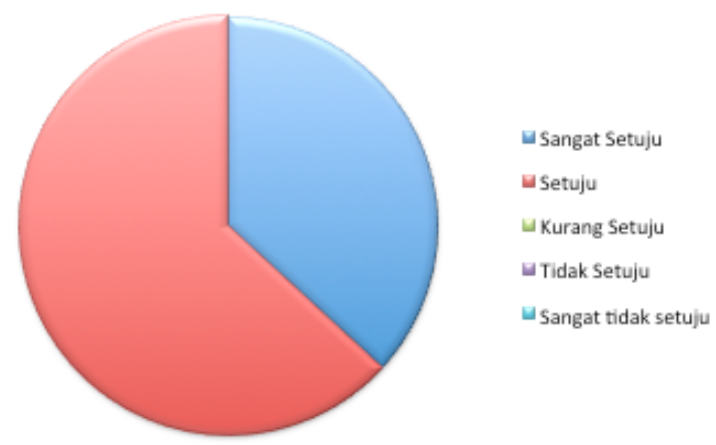

Gambar 1. Kriteria jawaban responden terkait fasilitas kolaborasi antar disiplin ilmu dalam repositori

Sumber: Berdasarkan hasil penelitian, 2019

Kolaborasi data penelitian juga mendorong tingkat kepercayaan publik terhadap hasil penelitian. Selain itu, hal ini sebagai salah satu upaya meningkatkan kualitas penelitian karena mekanisme peer review dapat berlangsung secara alamiah melalui pengujian data penelitian yang dapat dibuka publik. Dengan demikian, integritas peneliti dalam melakukan kegiatan penelitian semakin dapat dipertanggungjawabkan sesuai kaidah etik yang berlaku dalam komunitas ilmiah. Lembaga perlu membuat suatu kebijakan terkait mekanisme dari berbagi data penelitian dalam internal peneliti dan eksternal lembaga guna berbagi data untuk kolaborasi penelitian.

Kebijakan berbagi data sendiri dimulai sejak kegiatan penelitian direncanakan dengan memuat pernyataan kesetujuan (informed consent) pada saat pengambilan data dengan subjek manusia. Kemudian hal ini dituangkan ke dalam satu dokumen 
manajemen perencanaan data (data management planning). Pada saat penelitian berlangsung, pendokumentasian terhadap proses penciptaan data pun perlu diperhatikan secara cermat karena menyangkut penciptaan konteks data dan metode penggunaan kembali data.

Ketika penelitian telah selesai dilakukan, peneliti perlu memperhatikan hak akses terhadap data yang telah disimpan dalam repositori data melalui pengaturan konfigurasi akses pada sistem repositori. Lebih lanjut, data penelitian pun perlu diberikan lisensi untuk penggunaan lebih lanjut oleh peneliti lain untuk menghindari plagiat data atau hilangnya hak kekayaan intelektual peneliti atas data yang dihasilkan saat digunakan oleh pihak lain. Lisensi yang umumnya digunakan untuk perlindungan hak cipta pada data penelitian adalah creative common.

\section{SIMPULAN}

Kondisi pengelolaan repositori institusi pada lembaga riset yang berstatus Pusat Unggulan Ilmu Pengetahuan dan Teknologi (PUI) dilihat dari sisi kebijakan, infrastruktur, dan budaya organisasi sudah cukup baik dan perlu ditingkatkan pada beberapa aspek. Sebagian besar lembaga penelitian, pengkajian, dan penerapan telah memiliki kebijakan terkait pengelolaan repositori lembaga. Namun, kewajiban lembaga penelitian, pengkajian, dan penerapan untuk menyimpan keluaran berupa data penelitian pada repositori lembaga masih belum banyak dilakukan. Adapun dari sisi infrastruktur, seluruh lembaga penelitian, pengembangan, pengkajian, dan penerapan, telah memiliki repositori yang digunakan untuk mengelola keluaran penelitian berupa karya tulis ilmiah dan laporan penelitian. Namun, lembaga penelitian, pengkajian, dan penerapan dalam pengelolaan luaran penelitian berupa data penelitian belum banyak memiliki sistem repositori data penelitian. Pada sisi budaya organisasi, peneliti menyadari bahwa kolaborasi penelitian memiliki potensi besar dalam memanfaatkan repositori untuk pengelolaan data dan karya tulis ilmiah. Maka, harus ada upaya membangun kesadaran dalam mengelola data penelitian di level kelembagaan sampai level individu. Kegiatan sosialisasi, kampanye, dan bimbingan teknis diperlukan untuk membangun kesadaran pengelolaan data penelitian dengan memanfaatkan repositori data. Pembangunan budaya organisasi dapat mendorong pemanfaatan data secara bersama melalui repositori data sehingga kegiatan penelitian dapat berjalan secara efisien dan dipertanggungjawabkan. Untuk rekomendasi penelitian selanjutnya, penelitian dapat dilakukan terkait tema implementasi repositori data pada skala nasional agar dapat diimplementasikan. Ada dua opsi di antaranya sistem sentralisasi dan desentralisasi. Selain itu, penelitian ini juga dapat teliti mengenai studi dalam menentukan sistem yang paling sesuai dengan konteks peta riset di Indonesia.

\section{DAFTAR PUSTAKA}

Asmad, C. C., Mathar, T., Akbar, A. K., Arifin, N., Hijrana, Haruddin, ... Satriani. (2018). Tren perkembangan open access institutional repository pada perguruan tinggi di Indonesia. Khizanah Al-Hikmah: Jurnal Ilmu Perpustakaan, Informasi, Dan Kearsipan, 6(2), 168-180. https:// doi.org/10.24252/kah.v6i2a8 
Bates, J. (2017). The politics of data friction. Journal of Documentation, 74(2), 412429. https://doi.org/10.1108/JD-052017-0080

Charte, F., Charte, D., Rivera, A., del Jesus, M. J., \& Herrera, F. (2016). Ultimate multilabel dataset repository. In C. E. Martínez-Álvarez F., Troncoso A., Quintián H. (Ed.), International Conference on Hybrid Artificial Intelligence Systems (pp. 487-499). Springer. https:/ / doi.org//10.1007/978-3-31932034-2_41

Cheah, P. Y., Day, N. P. J., Parker, M., \& Bull, S. (2017). Sharing individuallevel health research data: Experiences, challenges and a research agenda. Asian Bioethics Review, 9(4), 393-400. https:/ / doi.org/10.1007/s41649-0170029-5

Fusi, F., Manzella, D., Louafi, S., \& Welch, E. (2018). Building global genomics initiatives and enabling data sharing: Insights from multiple case studies. OMICS: A Journal of Integrative Biology, 22(4), 237-247. https:/ / doi.org/10.1089/omi.2017.02 14

Groom, Q. J., Desmet, P., Vanderhoeven, S., \& Adriaens, T. (2015). The importance of open data for invasive alien species research, policy, and management. Management of Biological Invasions, 6(2), 119-125. https://doi.org/10.3391/mbi.2015.6.2 .02

Hamdi, A. S., \& Bahruddin, E. (2014). Metode penelitian kuantitatif aplikasi dalam pendidikan. Yogyakarta: Deepublish. Retrieved from https:/ / books.google.co.id/books?id $=$ nhwaCgAAQBAJ\&printsec $=$ frontco ver\&hl $=\mathrm{id} \# \mathrm{v}=$ onepage\& $\mathrm{q}=$ Teknik pengumpulan data yang lazim digunakan dalam mengumpulkan informasi kuantitatif\%2C yaitu kuesioner\%2C wawancara terencana $\% 2 \mathrm{C}$ tes $\% 2 \mathrm{C}$ observasi terencana $\% 2 \mathrm{C}$ inventarisasi $\% 2 \mathrm{C}$ skala rating $\% 2 \mathrm{C}$ ukuran biasa\&f=false

Higman, R., \& Pinfield, S. (2015). Research data management and opennes: The role of data sharing in developing institutional policies and practices. Program: Electronic Library and IInformation Systems, 49(4), 364-381. https:/ / doi.org/10.1108/PROG-012015-005

Irawan, D. E., \& Rachmi, C. N. (2018). Promoting data sharing among Indonesian scientists: A proposal of generic university-level Research Data Management Plan (RDMP). Research Ideas and Outcomes, 4(7), 1-13. https://doi.org/10.3897/ rio.4.e28163

Irawan, D. E., Darujati, C., Soebandhi, S., Hayati, F., \& Sari, D. A. P. (2018). How to extend your data lifetime: Research data management in Indonesia's context. In W. Striełkowski (Ed.), Proceedings of the 1st International Conference on Life, Innovation, Change and Knowledge (pp. 162-165). Atlantis Press. https://doi.org/10.2991/iclick18.2019 .33

Meeker, D., Jiang, X., Matheny, M. E., Farcas, C., D'Arcy, M., Pearlman, L., ... Ohno-Machado, L. (2015). A system to build distributed multivariate models and manage disparate data sharing policies: Implementation in the scalable national network for effectiveness research. Journal of the American Medical Informatics Association, 22(6), 1187-1195. 
https:// doi.org/10.1093/jamia/ocv01 7

Mueller-Langer, F., \& Andreoli-Versbach, P. (2018). Open access to research data: Strategic delay and the ambiguous welfare effects of mandatory data disclosure. Information Economics and Policy, 42(1), 20-34.

https:// doi.org/10.1016/j.infoecopol. 2017.05.004

Nassaji, H. (2015). Qualitative and descriptive research: Data type versus data analysis. Language Teaching Research, 19(2), 129-132. https:// doi.org/10.1177/13621688155 72747

Neylon, C. (2017). Building a culture of data sharing: Policy design and implementation for research data management in development research. Research Ideas and Outcomes, $3(2)$, 1-32. https:// doi.org/10.3897/rio.3.e21773

Undang-Undang Republik Indonesia Nomor 11 Tahun 2019 Tentang Sistem Nasional Ilmu Pengetahuan dan Teknologi. 13 Agustus 2019. Lembaran Negara Republik Indonesia Tahun 2019 Nomor 148. Jakarta. Retrieved from https://jdih.bssn.go.id/wpcontent/uploads/2019/10/UU-

Nomor-11-Tahun-2019.pdf

Rahman, M., \& Watabe, H. (2018). Online molecular image repository and analysis system: A multicenter collaborative open-source infrastructure for molecular imaging research and application. Computers in Biology and Medicine, 1(96), 233-24. https:// doi.org/10.1016/j.compbiom ed.2018.04.001

RDA Covid-19 Working Groups. (2020).
RDA Covid-19 working group recommendations and guidelines. Research Data Alliance (RDA). https://doi.org/10.15497/rda00046

Riyanto, S., Marlina, E., Subagyo, H., Triasih, H., \& Yaman, A. (2021). Metode penilaian kualitas data sebagai rekomendasi sistem repositori ilmiah nasional. BACA: Jurnal Dokumentasi Dan Informasi, 41(1), 1122.

https:// doi.org/10.14203/j.baca.v41i1 .544

UK multi-stakeholder group. (2020). Concordat on open research data. https://www.ukri.org/. Retrieved July 15, 2020, from https://www.ukri.org/wpcontent/uploads/2020/10/UKRI020920-

ConcordatonOpenResearchData.pdf

Ulum, A., \& Setiawan, E. (2016). Analisis konten dan kebijakan akses institutional repository. Pustakaloka, $8(1)$, 157. https:// doi.org/10.21154/pustakalok a.v8i1.476

Vasilevsky, N. A., Minnier, J., Haendel, M. A., \& Champieux, R. E. (2017). Reproducible and reusable research: Are journal data sharing policies meeting the mark? PeerJ, 5(3), 1-18. https://doi.org/10.7717/peerj.3208

Yaniasih, Ardiansyah, F., \& SulistyoBasuki. (2015). Analisis dan desain konseptual repositori institusi yang mendukung swaarsip peneliti di Lembaga Ilmu Pengetahuan Indonesia (Tesis) [IPB University, Bogor]. In IPB University. Retrieved from

https://repository.ipb.ac.id/handle/ 123456789/76945

Zuiderwijk, A., Shinde, R., \& Jeng, W. 
(2020). What drives and inhibits researchers to share and use open research data? A systematic literature review to analyze factors influencing open research data adoption. PLoS ONE, 15(9), 1-49. https://doi.org/ 10.1371/journal.pone.0239283 
